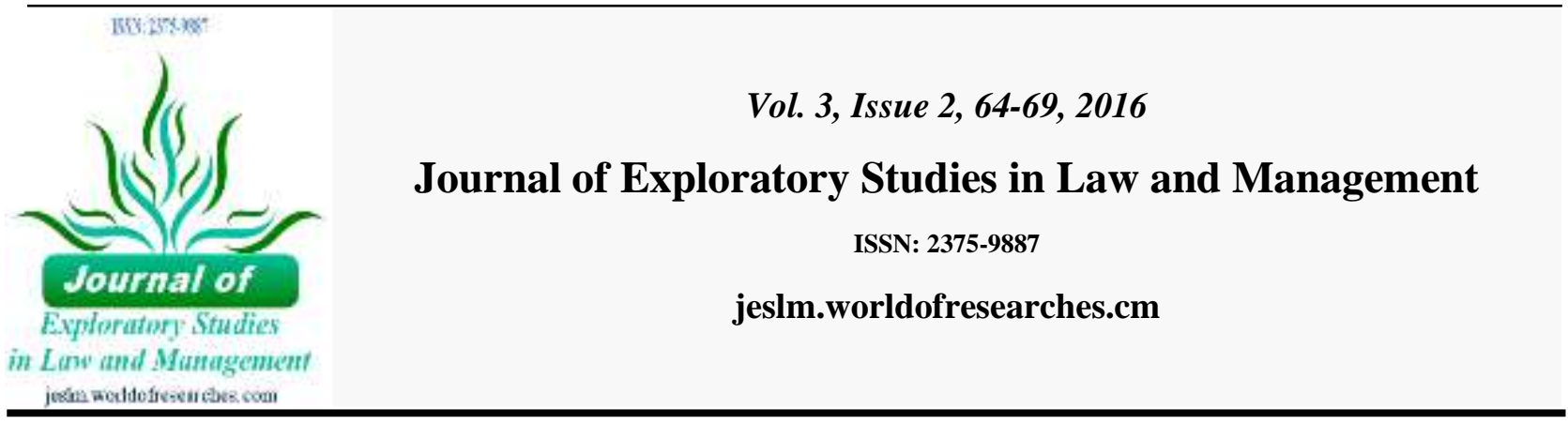

\title{
The role of Administrative Justice Court in tax disputes in Iran
}

\author{
Mohammad Reza Moravej ${ }^{*}$, Mostafa Seraji \\ Department of Public Law, Bandar Abbas Branch, Islamic Azad University, Bandar Abbas, Iran.
}

\begin{abstract}
A B S T R A C T
Tax trial has long preoccupied the minds of theorists of law. The dictatorship of rulers in the history with taxpayers and also the supreme powers, points and authorities of the tax system has led many elites and social groups to control the ruler's power and to make the tax receive methods lawful and the hearing to the conflicts between taxpayers and the government. Studying the trend and rules of Iran's law indicate that the mentioned hearings is of two types: the first phase is the responsibility of the internal organs of tax organization and since this organization is an administrative no a judicial system, the term administrative hearing has become common. In the next phase, specific Office references (quasi-judicial) have pronounced within the executive branch and under the supervision of the judicial authorities in this matter. After the first stage, if the taxpayers are dissatisfied with the outcome, they can turn to the second stage which is quasi-judicial proceedings. This study has been done to examine the role of the Administrative Justice Court in tax disputes of Iran.
\end{abstract}

Keywords: Taxes, Taxpayers, Tax Justice System, Tax Dispute Resolution Committee, The Court Of Administrative Justice.

\section{INTRODUCTION}

Tax trial has long preoccupied the minds of theorists of law. The dictatorship of rulers in the history with taxpayers and also the supreme powers, points and authorities of the tax system has led many elites and social groups to control the ruler's power and to make the tax receive methods lawful and the hearing to the conflicts between taxpayers and the government. Thus, with the spread of democratic ideas in the world, an institution as tax hearing was formed along with other legal entities.

Taxes are one of the costs that citizens pay to the government. Tax rates are set based on different rules and the taxpayers are informed tax through tax diagnosis papers. Taxpayers may protest against the amount of tax objection. One of the highest authorities in Iran that has jurisdiction over the dispute is the Court of Administrative Justice. Administrative Justice Court supervises over the performance of executive bodies and councils and commissions as a judicial authority and the supervision is done through the judicial investigations ${ }^{1}$.

\footnotetext{
* . Corresponding Author: Moravej, M. R.
}

To cite this article: Moravej, M. R., Seraji, M. (2016). The role of Administrative Justice Court in tax disputes in Iran. Journal of Exploratory Studies in Law and Management, 3 (2), 64-69. 
The qualification of Court of Administrative Justice was reckoned by the second quarter of the Court of Administrative Justice Act, passed in 2006. In order to fulfill the mentioned qualification, if the taxpayer has not protested in the lawful deadline, and there is no lawful agent to state the problem in the tax dispute conflict resolution council and the tax diagnosis paper has been issued to final tax license, so in this case and pursuant to paragraph 1 of Article 13 of the law mentioned above, taxpayer can protest against the decision of the tax administration in determining the claimed tax and request for the hearing in the Court of administrative justice. Also, due to the paragraph 2 of Article 13 of the law dealing with objections and complaints of the vote and the final decision on tax dispute resolution councils, violations of the laws and regulations or opposition to them is particularly in the jurisdiction of the Court of administrative justice authorities. However, the stipulator references in this paragraph are not restricted and have figurative aspect and each reference with the characteristics of specific administrative references with any title such as commission, Board, and council which are formed outside the judicial organization, except for those exceptional cases due to a specific law, are under the supervision of court and in case of complaint of the final approved votes, they are due to the qualification of court in hearing to the votes of the mentioned references. As a result of hearing to the protest against the final approved votes, all the other concerned references in tax dispute resolution such as the supreme tax council are in the qualification of Court of administrative justice ${ }^{2}$.

As was mentioned earlier, the Court of Administrative Justice is the reference to the final approved vote issued by all the tax authorities, so it is also considered as supreme formal Court of tax dispute resolution. The above-mentioned legal clause also stipulates that the complaint of the vote's references contained therein and similar references should only be in terms of violation of laws, regulations or disagree with them ${ }^{3}$. So, Court's review has merely the formal aspect in here, which means that if Branch of Administrative Justice Court has not diagnosed and annuls the final vote of tax dispute centers based on law, the retrial is given to another board or branch unless there is no subject for trial with annulment of the complaint and it will not enter the subject of hearing itself. The vote of the Administrative Justice Court is certain except in special cases. This paper presents the role of Administrative Justice Court in tax disputes in Iran in detail.

\section{CONFLICT THE VIOLATIONS OF THE EXECUTIVE AUTHORITIES OF THE LAW}

Before the Islamic Revolution in 1960, the law of establishing administrative council was approved but was never implemented and it is always remembered of the obsolete law in law reference books.

After the Islamic Revolution, there was concern that what should be done in case of the violation of executive authorities of the laws passed by Parliament and the limitations appointed by the legislator? Principles 126, 170 and 173 of the constitution of Islamic Republic of Iran were favorable responses to these concerns. The Administrative Justice Court supervision based on principles 170 and 173 and the stipulation of the establishment of the Administrative Justice Court, as a reference of administrative grievances, caused a supreme authority to trial the violations of the administrative authorities for the first time in Iran's history ${ }^{4}$.

Extended qualification jurisdiction of the Court of Administrative Justice in Article 11 of the law passed in 1981, and Article 13 of the law passed in 2006 that include various quasi-judicial references, indicates a legislative intention to monitor the lawfulness of law and regulations and executive decisions. In addition, the establishment of the Court of Administrative Justice was a response to concerns about the withdrawal of the executive branch of the limitations in the ordinary law because it was sometimes seen that executive authorities were out of the established regulations legislation and their personal interpretations in ordinary laws. The Court of 
Administrative Justice provides the possibility for citizens to prevent the implementation of these regulations.

\section{FAIR CONSOLIDATION OF TAXES}

The tax organization of the country, due to the key role of financial relationships of people and government, should consider the public benefits in receiving taxes on the one hand and guarantee the legal security of citizens on the other hand. In guaranteeing the legal security of citizens, the important thing is that the legal status of the taxpayer which is determined and predicted by law is not tarnished by administrative officers or tax authority. The centre to this issue is the provision of legal security of taxpayers. Law commitment is the main pillar of the lawful government. Lawful government means a government that is enclosed or confined to legal norms and therefore all actions of the government should be in the framework of these norms. This means that the government must comply with these norms in most cases. The law commitment principle involved following Administrative actions and regulations of the norms contained in the law.

In the field of Law commitment and its various aspects, we have to say that it is important in two respects:

On the one hand, the administrative official should be competent enough in the formation of decisions in the formal aspect. In public law, including tax law, non-qualification is the principle and qualification requires stipulations. In addition, the formal Law commitment, legal formalities is also important because it is essential to carry out the mentioned conditions to comply with administrative practice.

In this regard, formal Law commitment means applying qualification in legal frame which is of more importance. In this aspect, applying qualification is namely the implementation of the tasks and powers exercised by the officers and governing bodies which must comply with the law. Also, decisions of quasi-judicial bodies should also follow this principle. Meanwhile, tax officers and authorities are of particular importance: on the one hand, taxpayer rights must be respected and tax laws must guarantee their rights and the mentioned officers and references must protect them effectively, and on the other hand, effective and accurate monitoring is essential in this regard in terms of the public interest and the tax authorities position in securing these interests. The second aspect of the Law commitment principle is its natural aspect which is linked to functional Law commitment or administrative decision meaning that the act or decision must comply with the law. In this context, tax decisions and votes must still comply with the relevant legislation that is important accordingly.

\section{SUPERVISORY OF AUTHORITIES AND TAX OFFICERS}

As we all know, monitoring the tax officer and authorities is considered in both the intrinsic and extrinsic aspects. The supervision of the Court of Administrative Justice is an external monitoring that takes place on tax officer and authorities. The legal source of this monitoring can be found in paragraphs 1 and 2 of Article 13 of the Law of Administrative Justice Court that has an important role in preventing the violation of the formal cases of Law commitment principle (of the qualification and competence process) and sometimes has natural cases of Law commitment. A comprehensive look to the votes of the public board of Administrative Justice Court can specify the grounds of supervision of this reference on the Law commitment of the officers and reference authorities and in fact, will have an important role in the prevention of this violation by the 
mentioned officers and references in the future. One important aspects of judicial supervision of the Court of Administrative Justice is to monitor the formal Law commitment meaning the supervision of competent tax authorities and tax officials by their legal formalities. It should be noted that external supervision of the Administrative Justice Court on the above cases will be followed by numerous works in the reduction of administrative violations and increase of the Administrative health in the Tax Organization of the country ${ }^{3}$. In the above cases, it seems that the Public Board of Administrative Justice Court has imposed strict supervision and in total, the performance of this reference can be evaluated as favorable.

\section{THE CONDITIONS OF THE TAX DISPUTE IN ADMINISTRATIVE JUSTICE COURT}

The most supreme Administrative Court and the last step that the taxpayer can refer to protest is Administrative Justice Court. If the payer of the tax or the taxpayer has not protested against the tax diagnosis paper in the legal deadline and there is no legal agent in order to state the problem in the Tax Dispute Resolution Council of Magistrates and the tax diagnosis paper has led to the issuance of the final tax paper, then the taxpayer can request the trial in the Administrative Justice Court due to the paragraph 1 of Article 13 of Administrative Justice Court law as a protest against the decision of Tax Administration in determining the claimed tax.

Paragraph 2 of the Article 13 of law of direct taxes is also notable in this regard. Accordingly, hearing to the protests and complaints of the final votes and decisions of Tax Disputes Boards is solely in the qualification of Administrative Justice Court in terms of the violation of rules and regulations or opposing them. However, the stipulator references in this paragraph are not restricted and have figurative aspect and each reference with the characteristics of specific administrative references with any title such as commission, Board, and council which are formed outside the judicial organization, except for those exceptional cases due to a specific law, are under the supervision of court and in case of complaint of the final approved votes, they are due to the qualification of court in hearing to the votes of the mentioned references. As a result of hearing to the protest against the final approved votes, all the other concerned references in tax dispute resolution such as the supreme tax council are in the qualification of Court of administrative justice. The expert of economic rights continues: Administrative Justice Court should be named as the supreme formal reference of tax disputes resolution because the final issued votes reference is of all the conflict dispute resolution authorities. Moreover, the mentioned legal paragraph stipulates that the complaint of the votes of the mentioned references in this and the similar references should only be in terms of violation of the rules and regulations or be opposite to them. So, the court's trial in here is merely formal meaning that if the branch of Administrative Justice Court does not know it based on the Law and annuls the final vote of tax dispute resolution councils, the retrial would be given to another branch unless the annulment of the vote of the subject matter, there is no subject for the trial in which this court does not enter ${ }^{\mathbf{1}}$. Administrative Justice Tribunal is final except in special cases. He points out that if the implementation of decisions and actions of the tax authorities would cause damage, a branch that handled the original case can issue the interim order to suspend operations until final disposition of the complaint.

\section{CHRONOLOGY IN THE COURT OF JUSTICE AND THE SUPREME TAX COUNCIL}

In cases in which taxpayers have the right to complaint to the Supreme Tax Council, it is better for them to use this right first and formal protest against the vote of the especial administrative reference would not be in all the competent references of the Administrative Court. 
Court has the right to hear to the absolute definite votes of the specific administrative references "in terms of violations of the laws and regulations or disagree with them", unless in cases exception to the law. Accordingly, the Court of Administrative Justice is competent for the formal hearing of the votes of the Supreme Council tax branches in addition to the competence of formal hearing to complaints to the final votes of tax dispute resolution bodies and there is no legal restrictions for the simultaneous making an action from the taxpayer in the Court and the Supreme tax Council. According to the fact that there is no deadline considered for reference to court in the law, the protester can complain about the final votes tax dispute resolution bodies to the Supreme Council tax up to one month after the issuance based on Article 251 of the law of direct taxes and the competence of the council in this case in formal ${ }^{2}$. Also, the protestor can complain the tax dispute resolution bodies' votes at the same time according to paragraph 2 of Article 13 of the administrative court law to the Court and that the Court's review in this regard is formal. Moreover, there is the possibility for the protestor to first complain about the Supreme tax Council and if it issues a vote against him, can protest against the Council's vote to the Administrative Court. Taxpayers can appeal to the Court of administrative justice as the supreme reference of hearing in following their protests, but it should be noted that the Court's review is formal.

\section{CONCLUSION}

In the preface to the Iranian Constitution, protecting the right of people and the Islamic justice are predicted that includes all social and individual aspects of the residents and citizens of the Islamic Republic of Iran and to emphasize the importance of Islamic justice in the judicial system, a verse of the Holy Quran is referenced and cited: "be just when passing judgment among people".

Also, the establishment of special courts such as those the judgment of the quasi-judicial authorities in some countries is not prohibited in the Constitution of the Islamic Republic of Iran and addressing financial and legal disputes between individuals and the government is not exclusively monopolized in the hands of the judiciary system. In addition, it is inferred from the numerous provisions of the Constitution and other mother laws and also the necessity of relying on Islamic principles and regulations and principles of justice that judging by any form and on any reference should be competent and unique and its investigations should be away from any person or party affiliation and attitudes.

Principle 34 of the Constitution appointed that: "justice is the inalienable right to everyone and everybody can refer to competent courts for justice. All citizens have the right to access such courts and nobody can be deprived of the right of referring to a court that is given the right of referring by the law". Accordingly, references should be open to all and their formalities and procedures should not be annoying or costly for the client.

\section{REFERENCES}

1. Rostami, V. (2009). Fair hearing in the administrative authorities of Iran, Tehran, Gerayesh publishing. [Persian]

2. Taheri Tari, M. M. (2011). The principle of equality and tax justice and human rights mirror and the new tax laws, Tehran, Institute of law Studies and Research. [Persian]

3. Abharian, H. (1993). Tax Dispute Resolution Councils, Journal of Finance, 1994, Issue 3. Fall-Winter. [Persian] 
4. Shakoorpoor Shaqlan, H. (2012). Developments in Iran Tax Procedure Code, Public Law Master's thesis, University of Shahid Beheshti Court of Administrative Justice law of Organizations and Procedure Act, passed in 2011.Constitution of the Islamic Republic of Iran. [Persian] 